\title{
Environmental Tobacco Smoke
}

National Cancer Institute

\section{Source}

National Cancer Institute. Environmental Tobacco Smoke. NCI Thesaurus. Code C2434.

Smoke that is emitted from burning tobacco, including cigarette, pipe and cigar, and from tobacco smoke exhaled by smokers. Environmental tobacco smoke consists of a huge variety of chemicals that are produced during the burning of tobacco. Among them are known or suspected toxicants, carcinogens and respiratory irritants, including nicotine, ammonia, formaldehyde, sulfur dioxide, acrolein, hydrog en cyanide, phenol, nitrogen oxide, polycyclic aromatic hydrocarbons, N-Nitrosamines and radionuclides. Environmental tobacco smoke has numerous adverse health effects, is mutagenic and is a known human carcinogen that is associated with an increased risk of developing lung cancer. $(\mathrm{NCl} 05)$ 